\title{
The Extension Services of the Ifugao State University, School Year 2012-2015: Basis for a Community Enhancement Program
}

\author{
Eva Marie Codamon-Dugyon \\ ${ }^{1}$ Ifugao State University, Extension and Training Department / College of Advanced Education, \\ Main Campus, Nayon, Lamut, Ifugao, Philippines 3605
}

\begin{abstract}
This study aimed to assess the extension programs and services of the Ifugao State University (IFSU) along education, livelihood generation, health and wellness, good governance and peace \& order, environmental awareness and protection, and organizational linkages during the School Year 2012-2015. This is a descriptive research using a questionnaire to gather data. Frequency, mean and t-test were used as statistical tools. There were 23 implementers and 210 beneficiaries who were utilized as respondents in the study. Results showed that the extension programs and services of IFSU were perceived by the implementers as "less implemented", while the beneficiaries perceived them as "implemented". The two groups of respondents were "involved". A significant difference existed in the ratings between the two groups of respondents on the implementation of all extension programs and services with the exception of environmental management. Meanwhile, there was no significant difference in the perception of both respondents on their involvement in extension programs and services along livelihood generation, good governance, peace and order, and organizational linkages. Implementers and beneficiaries both considered the item "there is no proper monitoring and evaluation of the extension projects conducted" as the most encountered problem in the implementation of University extension programs and projects.
\end{abstract}

Keywords: extension programs, services, community development, beneficiaries

\section{Introduction}

Extension, as one of the trifocal functions of Higher Education Institutions (HEIs) is perceived as a catalyst of development in the midst of today's complex society. The need for extension services has been growing exponentially not only in the Philippine HEIs but also in other countries because community extension is where reaching out, touching lives, community empowerment and collaboration exist. In its broadest sense, extension is an educational process with communication being its core component. Van den Ban and Hawkins (1996) define the term extension as the conscious use of communication of information to help people form sound opinions and make good decisions. As a system, extension facilitates the access of farmers, their organizations and other market actors to knowledge, information and technologies; facilitates their interaction with partners in research, education, agribusiness, and other relevant institutions; and assists them to develop their own technical, organizational and managerial skills and practices (Christoplos, 2010).

Relative to this, the Commission on Higher Education mandates institutions of higher learning like State Universities and Colleges (SUCs) to respond to the call for societal transformation. With this, educational institutions initiated and implemented an array of extension programs and services with the end in view to effect change and improve community life.

For its part, the Ifugao State University (IFSU) being the lone HEI in Ifugao, carries the mission to provide quality instruction, research and extension services to bring about educated individuals endowed with professional and entrepreneurial skills who will take the lead in enhancing sustainable development towards improved quality of life This portrays IFSU's responsibility as an agent of change as well as its leadership in knowledge creation and transmission through the interface of instruction, research and extension. It is said that extension plays a significant role in the knowledge-creation process and therefore is instrumental in shaping communities. Extension's goal is to teach people things that make their life better. It is within this context that institutions with corporate responsibilities design their extension programs that bring about the required knowledge, skills and resources to the communities in their quest for transformed lives.

The IFSU extension programs and services are being implemented by the Extension and Training Department of the university through community development programs which are designed primarily to alleviate poverty, reduce illiteracy, increase security of livelihood, promote health and wellness, strengthen governance that sustains human development, and protect and conserve the environment. These services, being implemented in the first and second districts of the province of Ifugao and neighboring provinces are focused on capability building through the conduct of livelihood skills training and education, technical assistance and advisories, and the transfer of technology to members of the communities in need. However, there is no study yet conducted on the extent of implementation and involvement in extension programs and services of IFSU by the implementers and beneficiaries.

Purpose of the Study

This study was undertaken to assess the extension programs and services of the Ifugao State University, School Year 2012-2015 with the aim of generating information on the extent of implementation and involvement of extension 


\section{International Journal of Science and Research (IJSR) \\ ISSN (Online): 2319-7064}

Index Copernicus Value (2013): 6.14 | Impact Factor (2015): 6.391

implementers and beneficiaries of IFSU extension programs and services, as well as the problems encountered by them in order to guide improvements in extension work plans and practices. It investigated on the core programs namely: health and wellness, education, livelihood generation, good governance, and environmental awareness and protection, and organizational linkages.

\section{Methodology}

\subsection{Research Method}

This study used descriptive method of research using questionnaire to assess the extent of implementation and involvement of IFSU extension implementers and beneficiaries of the university extension programs and services along education, livelihood generation, health and wellness, good governance and peace \& order, environmental awareness and protection, and organizational linkages.

\subsection{Research Respondents}

The respondents of the study composed of two groups - (1) the implementers, and (2) the beneficiaries of the extension programs and services of IFSU Main campus. The first group of respondents were the extension implementers composed of the extension coordinators of the colleges and other faculty members who were involved in extension projects and activities of the campus, as per record from 2012 to 21015. Out of 27 questionnaires distributed, only the 23 retrieved questionnaires for implementers were used in this study. Meanwhile, the second group of respondents were the beneficiaries of the extension programs and services of the university in the 11 barangays/ communities, where extension activities were undertaken since 2012 to 2015. For all these barangays/ communities, they were given the same number of questionnaires; that is, 20 questionnaires in each barangay/community. The 20 respondents in every barangay/community were the recipients of the six extended areas considered in this study. The total 220 beneficiaryrespondents were chosen based on the record of the extension staff and coordinators who knew well on their participation and attendance during the conduct of trainings.

\subsection{Research Instrument}

The study employed questionnaire as tool to generate data from extension implementers and beneficiaries. The instrument was adopted from the studies of Bidad and Campiseño (2010) and Tacbas, et al. (2010). Slight modifications of the instrument were made.

The questionnaire was used to obtain information on the extent of implementation and involvement of respondents in extension programs and services, and the problems encountered by them in the implementation of extension programs and services of IFSU Main Campus. The respondents were required to answer on a five-point scale as follows:

A. Extent of Implementation
\begin{tabular}{|c|c|c|c|}
\hline Scale & Range & $\begin{array}{c}\text { Qualitative } \\
\text { Description }\end{array}$ & $\begin{array}{c}\text { Definition of Qualitative } \\
\text { Description }\end{array}$ \\
\hline 5 & $4.20-5.00$ & $\begin{array}{c}\text { Very well } \\
\text { implemented }\end{array}$ & $\begin{array}{c}\text { Priority is always shown and is } \\
\text { highly implemented }\end{array}$ \\
\hline 4 & $3.40-4.19$ & $\begin{array}{c}\text { Well } \\
\text { implemented }\end{array}$ & $\begin{array}{c}\text { Priority is always shown and is } \\
\text { always implemented }\end{array}$ \\
\hline 3 & $2.60-3.39$ & Implemented & $\begin{array}{c}\text { Priority is often shown and is } \\
\text { implemented }\end{array}$ \\
\hline 2 & $1.80-2.59$ & $\begin{array}{c}\text { Less } \\
\text { Implemented }\end{array}$ & $\begin{array}{c}\text { Priority is often shown but not } \\
\text { implemented }\end{array}$ \\
\hline 1 & $1.00-1.79$ & $\begin{array}{c}\text { Never } \\
\text { Implemented }\end{array}$ & $\begin{array}{c}\text { Priority is seldom shown and } \\
\text { not implemented }\end{array}$ \\
\hline
\end{tabular}

\section{B. Extent of Involvement}

\begin{tabular}{|c|c|c|c|}
\hline Scale & Range & $\begin{array}{c}\text { Qualitative } \\
\text { Description }\end{array}$ & $\begin{array}{c}\text { Definition of Qualitative } \\
\text { Description }\end{array}$ \\
\hline 5 & $4.20-5.00$ & $\begin{array}{c}\text { Very well } \\
\text { involved }\end{array}$ & $\begin{array}{c}\text { Interest is always shown and is } \\
\text { highly attended }\end{array}$ \\
\hline 4 & $3.40-4.19$ & Well involved & $\begin{array}{c}\text { Interest is always shown and is } \\
\text { always attended }\end{array}$ \\
\hline 3 & $2.60-3.39$ & Involved & $\begin{array}{c}\text { Interest is often shown and is } \\
\text { attended }\end{array}$ \\
\hline 2 & $1.80-2.59$ & Less Involved & $\begin{array}{c}\text { Interest is often shown but not } \\
\text { attended }\end{array}$ \\
\hline 1 & $1.00-1.79$ & $\begin{array}{c}\text { Never } \\
\text { Involved }\end{array}$ & $\begin{array}{c}\text { Interest is seldom shown and not } \\
\text { attended }\end{array}$ \\
\hline
\end{tabular}

\subsection{Statistical Treatment of Data}

The statistical tools employed in the analysis of data were frequency count, mean, and t-test. Frequency count and ranking were used to determine the problem most encountered by the respondents.

The weighted mean was used to assess the extent of the implementation and involvement of implementers and beneficiaries. T-test was utilized to determine the significant difference in the ratings of extension implementers and beneficiaries in the implementation and their involvement in the extension programs of IFSU. Statistical test was set at 0.05 level of significance.

\section{Results and Discussion}

\subsection{Extent of implementation of Extension Programs and Services of IFSU Main Campus}

Table 1: Extent of implementation of the Extension programs \& Services of IFSU Main Campus

\begin{tabular}{|c|c|c|c|c|}
\hline \multirow{2}{*}{ Indicators } & \multicolumn{2}{|c|}{ Implementers } & \multicolumn{2}{c|}{ Beneficiaries } \\
\cline { 2 - 5 } & Mean & Description & Mean & Description \\
\hline Education & 2.30 & LI & 3.13 & I \\
\hline Livelihood generation & 2.78 & I & 3.08 & I \\
\hline Health and Wellness & 2.52 & LI & 3.29 & I \\
\hline $\begin{array}{c}\text { Good governance \& } \\
\text { Peace and Order }\end{array}$ & 2.39 & LI & 2.89 & I \\
\hline $\begin{array}{c}\text { Environmental } \\
\text { Protection \& Awareness }\end{array}$ & 1.91 & LI & 2.68 & I \\
\hline Organizational Linkages & 1.61 & NI & 2.46 & LI \\
\hline General Mean & $\mathbf{2 . 2 5}$ & LI & $\mathbf{2 . 9 1}$ & I \\
\hline
\end{tabular}




\section{International Journal of Science and Research (IJSR) \\ ISSN (Online): 2319-7064}

Index Copernicus Value (2013): 6.14 | Impact Factor (2015): 6.391

Legend:
4.20-5.00 Very well implemented (VWI)
3.40-4.19 Well implemented (WI)
2.60-3.39 Implemented (I)
1.80-2.59 Less Implemented (LI)
1.00-1.79 Never Implemented (NI)

Table 1 shows the extent of implementation of the extension programs and services of the Ifugao State University (IFSU) Main Campus. Out of the six indicators, only livelihood generation program was rated by implementers as "Implemented". It can be gleaned from the Table that the general mean rating is 2.25 and described as "Less implemented" by the implementers. This signifies that respondent implementers recognized that education, health and wellness, good governance and peace \& order, environmental protection and awareness, and organizational linkages are the extension programs that they are still obliged to implement and put into action in the service communities. In contrast, the Table also manifests that all indicators except organizational linkages were rated as "Implemented" by the beneficiaries. This was supported by the computed general mean of 2.91. This means that beneficiaries took cognizance of the implementation of extension activities as they also benefited from them.

3.2 Extent of Involvement of Implementers and Beneficiaries of Extension Programs and Services of IFSU Main Campus

Table 2: Extent of involvement of the Implementers and Beneficiaries on the Extension Programs and Services of IFSU

\begin{tabular}{|c|c|c|c|c|}
\hline Services/ Programs & \multicolumn{2}{|c|}{ Implementers } & \multicolumn{2}{c|}{ Beneficiaries } \\
\cline { 2 - 5 } & Mean & Description & Mean & Description \\
\hline Education & 2.65 & I & 3.19 & I \\
\hline Livelihood generation & 2.69 & I & 3.07 & I \\
\hline Health and Nutrition & 2.69 & I & 3.22 & I \\
\hline $\begin{array}{c}\text { Good governance \& } \\
\text { Peace and Order }\end{array}$ & 2.87 & I & 2.78 & I \\
\hline $\begin{array}{c}\text { Environmental } \\
\text { Management }\end{array}$ & 2.78 & I & 2.67 & I \\
\hline $\begin{array}{c}\text { Organizational } \\
\text { Linkages }\end{array}$ & 2.00 & LI & 2.37 & LI \\
\hline General Mean & $\mathbf{2 . 6 1}$ & I & $\mathbf{2 . 8 7}$ & I \\
\hline
\end{tabular}

Legend:
4.20-5.00
Very well involved (VWI)
$3.40-4.19$
Well involved (WI)
2.60-3.39
$1.80-2.59$
Involved (I)
Less Involved (LI)
$1.00-1.79$
Never Involved (NI)

Table 2 manifests the extent of involvement of the implementers and beneficiaries on the extension programs and services of IFSU. The findings show that only one indicator was rated by both respondents as "Less Involved". This signifies that both respondent implementers and respondent beneficiaries perceive organizational linkages as one of the extension programs of IFSU main campus where they are still impelled to be involved. The rest of the extension programs and services were rated by them as
"Involved" with the computed general means of 2.61 and 2.87 , respectively.

3.3 Problems Encountered by the Respondents in the Implementation of Extension Programs and Services of IFSU Main Campus

Table 3: Problems encountered by the Implementers and Beneficiaries in the Implementation of the Extension Programs and Services of IFSU

\begin{tabular}{|c|c|c|c|c|}
\hline Items & \multicolumn{2}{|c|}{ Implementers } & \multicolumn{2}{c|}{ Beneficiaries } \\
\cline { 2 - 5 } & Frequency & Rank & Frequency & Rank \\
\hline $\begin{array}{c}\text { 1. There is no work and } \\
\text { financial plan to guide the } \\
\text { project. }\end{array}$ & 2 & $8^{\text {th }}$ & 82 & $3^{\text {rd }}$ \\
\hline $\begin{array}{c}\text { 2. There are no sufficient } \\
\text { materials and tools for better } \\
\text { learning process. }\end{array}$ & 9 & $5^{\text {th }}$ & 97 & $2^{\text {nd }}$ \\
\hline $\begin{array}{c}\text { 3. There are no sufficient } \\
\text { funds for extension activities } \\
\text { (i.e. trainings, } \\
\text { demonstrations). }\end{array}$ & 11 & $4^{\text {th }}$ & 55 & $6^{\text {th }}$ \\
\hline $\begin{array}{c}\text { 4. Transportation is not } \\
\text { available all the time. }\end{array}$ & 14 & $3^{\text {rd }}$ & 48 & $7^{\text {th }}$ \\
\hline $\begin{array}{c}\text { 5. Extension workers are } \\
\text { incompetent and unprepared. }\end{array}$ & 1 & $9^{\text {th }}$ & 14 & $14^{\text {th }}$ \\
\hline $\begin{array}{c}\text { 6. Trainers are not coming } \\
\text { regularly for the extension } \\
\text { activities. }\end{array}$ & 4 & $7^{\text {th }}$ & 46 & $8^{\text {th }}$ \\
\hline $\begin{array}{c}\text { 7. Period of classes/ trainings } \\
\text { is too short. }\end{array}$ & 15 & $2^{\text {th }}$ & 81 & $4^{\text {th }}$ \\
\hline $\begin{array}{c}\text { 8. Extension workers/ faculty } \\
\text { are not given incentives. }\end{array}$ & 14 & $3^{\text {rd }}$ & 24 & $12^{\text {th }}$ \\
\hline $\begin{array}{c}\text { 9. There is limited workload } \\
\text { equivalent for extension } \\
\text { workers/ faculty engaged in } \\
\text { extension activities. } \\
\text { services conducted. }\end{array}$ & 11 & $4^{\text {th }}$ & 30 & $10^{\text {th }}$ \\
\hline $\begin{array}{c}\text { 10. Training time coincides } \\
\text { with work at home, farm, etc. }\end{array}$ & 8 & $6^{\text {th }}$ & 57 & $5^{\text {th }}$ \\
\hline $\begin{array}{c}\text { 11. Participants are always } \\
\text { absent from class/ training. }\end{array}$ & 1 & $9^{\text {th }}$ & 29 & $11^{\text {th }}$ \\
\hline $\begin{array}{c}\text { 12. Participants use their own } \\
\text { materials for the return } \\
\text { demonstration. }\end{array}$ & 1 & $9^{\text {th }}$ & 17 & $13^{\text {th }}$ \\
\hline $\begin{array}{c}\text { 13. Linkage partners are not } \\
\text { doing their responsibilities as }\end{array}$ & 2 & $8^{\text {th }}$ & 32 & $9^{\text {th }}$ \\
\hline
\end{tabular}

Table 3 presents the problems met by both respondents in the implementation and involvement in the extension programs and services of IFSU main campus. Geronimo (2001) and Bidad and Campiseño (2010) emphasized that in the process of effecting community development, many difficulties arise as these are inevitable. In this study, data show that the two groups of respondents have unanimously identified the same item as their most encountered problem. Both respondents considered item 14 which is, "There is no proper monitoring and evaluation of the extension projects/ services conducted" as their number one problem. Likewise, while the implementers ranked item 7 which is "Period of classes/ trainings is too short" as their $2^{\text {nd }}$ most encountered problem, 


\section{International Journal of Science and Research (IJSR) \\ ISSN (Online): 2319-7064}

Index Copernicus Value (2013): 6.14 | Impact Factor (2015): 6.391

the beneficiaries ranked the same as $4^{\text {th }}$. Understandably, the implementers also considered "Transportation is not available all the time", "Extension workers/ faculty are not given incentives", and "There is limited workload equivalent for extension workers/ faculty engaged in extension activities" as their other top problems.

It can be deduced from the results of the study that the problems identified by the implementers may have a bearing on the extent of implementation of extension programs and services by the extension coordinators and/or implementers. Hence, extension programs are less implemented by the faculty members in the main campus. Meanwhile, in spite of the problems encountered during the conduct and/or implementation of extension programs and services, there is no indication that extension implementers in the campus are losing eagerness and commitment to share their expertise to the clienteles. There is rather an indication that faculty members are involved in the extension programs and services as reflected in the results of this study. The faculty members' involvement in extension programs and services, notwithstanding the problems may also be attributed to the fact that job description of faculty members in IFSU is distributed according to academic ranks. IFSU PolicyGuidelines No. 68-2015 re: Implementation of workload for All Faculty Members in the University as per NBC 461 and IFSU Code expressly provides that as a faculty member moves up the ladder of their academic rank, they must be more involved in the four-fold functions of the University, namely: instruction, research, extension, and production in adherence to the "equal pay for equal work" principle.

On the other hand, the beneficiaries considered the following as other drawbacks: "There are no sufficient materials and tools for better learning process"; "There is no work and financial plan to guide the project"; "Period of classes/ trainings is too short"; and Training time coincides with work at home, farm, etc." as their other most encountered problems. To them, training materials and training class periods fall short for them to efficiently acquire and develop knowledge and skills. This is in agreement with the study of Bidad and Campiseño (2010) that stressed out that beneficiaries felt the needs of lengthening the period of time of trainings.

3.4 Difference in the Ratings of Implementers and Beneficiaries on the Implementation of Extension Programs and Services of IFSU Main Campus

Table 4: Significant Difference in the Ratings of implementers and Beneficiaries on the Implementation of Extension Programs and Services of IFSU

\begin{tabular}{|c|c|c|c|c|}
\hline Indicators & Implementers & Beneficiaries & XD & t-value \\
\hline Education & 2.30 & 3.13 & 0.81 & $5.72^{*}$ \\
\hline $\begin{array}{c}\text { Livelihood } \\
\text { generation }\end{array}$ & 2.78 & 3.08 & 0.28 & $4.60^{*}$ \\
\hline $\begin{array}{c}\text { Health and } \\
\text { Wellness }\end{array}$ & 2.52 & 3.29 & 0.76 & $6.86^{*}$ \\
\hline $\begin{array}{c}\text { Good } \\
\text { governance \& } \\
\text { Peace and Order }\end{array}$ & 2.39 & 2.89 & 0.43 & $2.46^{*}$ \\
\hline Environmental & 1.91 & 2.68 & 0.7596 & $1.36 \mathrm{~ns}$ \\
\hline
\end{tabular}

\begin{tabular}{|c|c|c|c|c|}
\hline $\begin{array}{c}\text { Protection \& } \\
\text { Awareness }\end{array}$ & & & & \\
\hline $\begin{array}{c}\text { Organizational } \\
\text { Linkages }\end{array}$ & 1.61 & 2.46 & 0.8383 & $3.24 *$ \\
\hline
\end{tabular}

Legend:

*- Significant $\alpha-0.05 \mathrm{t}-\mathrm{v}-1.96$

ns-Not significant

Table 4 reveals that the implementers and beneficiaries obtained different ratings on the extent of implementation of IFSU's extension programs and services. When the data were subjected to t-test, the computed t-results were more than the tabled value of 1.96 at 0.05 level of confidence. This implies that there exist a significant difference in the ratings between the two groups of respondents on the implementation of all extension programs and services with the exception of environmental protection and awareness. The results indicate that while the implementers perceive that they "less implemented" extension services along education, livelihood generation, health and wellness, good governance and peace and order, and organizational linkages, the beneficiaries, on the one hand, perceive that the same were "implemented", which means that priority was shown and that the extension services were implemented, and the beneficiaries were also benefited.

3.5 Difference in the Ratings of Implementers and Beneficiaries on their Involvement in IFSU Extension Programs and Services

Table 5: Significant Difference in the Perceptions of Implementers and Beneficiaries on their Involvement of Extension Programs and Services of IFSU

\begin{tabular}{|c|c|c|c|c|}
\hline Indicators & Implementers & Beneficiaries & XD & t-Value \\
\hline Education & 2.65 & 3.19 & 0.52 & $4.63^{*}$ \\
\hline $\begin{array}{c}\text { Livelihood } \\
\text { generation }\end{array}$ & 2.69 & 3.07 & 0.37 & $.48 \mathrm{~ns}$ \\
\hline Health and Wellnes & 2.69 & 3.22 & 0.51 & $2.14^{*}$ \\
\hline $\begin{array}{c}\text { Good governance \& } \\
\text { Peace and Order }\end{array}$ & 2.87 & 2.78 & 0.10 & $1.23 \mathrm{~ns}$ \\
\hline $\begin{array}{c}\text { Environmental } \\
\text { Protection and } \\
\text { Awareness }\end{array}$ & 2.78 & 2.67 & 0.12 & $2.01^{*}$ \\
\hline $\begin{array}{c}\text { Organizational } \\
\text { Linkages }\end{array}$ & 2.0000 & 2.37 & 0.35 & $1.51 \mathrm{~ns}$ \\
\hline
\end{tabular}

Legend:

*- Significant $\alpha-0.05 \mathrm{t}-\mathrm{v}-1.96$

ns-Not significant

Table 5 manifests that the two groups of respondents have similar perception on the extent of their involvement in two extension services. These were shown by the means of 2.69 and 2.86 for implementers and 3.06 and 2.76 for beneficiaries, which fall under the description "involved" particularly on livelihood generation, good governance and peace $\&$ order. Both respondents also perceived that there was one extension service that they were "less involved", as supported by the means of 2.00 for implementers and 2.35 for beneficiaries in organizational linkages. The mean differences of these three indicators were $0.37,0.10$, and 0.12 that resulted to t-test values of $0.48,1.23$ and 1.51 which were less than the tabled value of 1.96 at 0.05 level of significance. Thus, there is no significant difference in the 


\section{International Journal of Science and Research (IJSR) \\ ISSN (Online): 2319-7064}

Index Copernicus Value (2013): 6.14 | Impact Factor (2015): 6.391

perception of both respondents on their involvement in extension programs and services on livelihood generation, good governance and peace \& order, and organizational linkages.

\section{Conclusion}

Based on the findings of the study, the following conclusions were made:

1)The extension services of IFSU along education, livelihood, health and wellness, good governance and peace \& order, environmental protection and awareness are perceived by the beneficiaries as "implemented". Meanwhile, only one indicator, that is, livelihood generation is perceived by implementers as "implemented". Both respondents rated organizational linkages as "less implemented".

2) The implementers and beneficiaries perceived the extended program on education, livelihood generation, health and wellness, good governance and peace \& order, and environmental protection and awareness as "involved".

3) The implementers and the beneficiaries both considered the problem "there is no proper monitoring and evaluation of the extension projects conducted" as the most encountered predicament in the implementation of extension programs and projects.

4) There is significant difference in the ratings provided by both respondents on the extent of implementation of the extension programs and services of IFSU along education, livelihood generation, health and wellness, good governance and peace \& order, and organizational linkages. Implementers perceived that most extension programs and services of IFSU main campus as "less implemented". On the contrary, beneficiaries regarded the university's extension and services as "implemented".

5)There is no significant difference in the perceptions of the implementers and beneficiaries on their involvement in the extension services of IFSU along livelihood generation, good governance and peace $\&$ order, and organizational linkages.

\section{Recommendations}

Based on the findings and conclusion of the study, the following recommendations are forwarded:

1)Implementation of university's key extension programs and services along education, livelihood generation, health and wellness, good governance and peace \& order, environmental protection and awareness, and organizational linkages by the extension implementers should be improved and intensified to have greater impact on the communities.

2)IFSU through the Extension and Training department should exert more effort to get the people (both implementers and beneficiaries) involve in the university's extension programs and services (a) by vigorously pursuing the incentive scheme for faculty members involved in the university extension programs and services to boost their morale, thereby, encouraging active involvement and participation; and (b) by augmenting budget allocation for extension projects and activities to be able to provide sufficient materials and tools for better learning process on the part of the beneficiaries.

3) Regular and strict monitoring and evaluation of the extended programs and services should be conducted and/or intensified by integrating it in the whole extension program package of the extension implementers.

4)A study be made on the impact of extension programs and services of the whole IFSU system to determine their significance.

\section{References}

[1] Bidad, C. D. \& Campiseño, E. R. (2010). Community Extension Services of SUCs in Region IX: Basis for a Sustainable Community Enhancement Program. EInternational Scientific Research Journal, 2(3)Retrieved December 12, 2015 from http://www.eisrjc.com.

[2] Christoplos, I. (2010). Mobilizing the Potential of Rural and Agricultural Extension. Neuchatel Group.

[3] Geronimo, Marites C. (2006). "The Involvement of Teacher Education Graduates in Community Development Activities". Philippine Normal University, Alicia, Isabela

[4] IFSU Policy Guidelines No. 68-2015. Implementation of Workload for All Faculty Members in the University as per NBC 461 and IFSU Code

[5] Tacbas, Lauro B., De Vera, Mariana, Romo, Necy Cesaria V. (2010). The Effectiveness of the Extension Programs of the University of Northern Philippines, School Year 2005-2008. UNP Research Journal Vol. XIX, January - December 2010.

[6] Van den Ban, A.W. and Hawkins, H.S. (1996). Agricultural Extension. 2 ed. Osney Mead, Oxford: Blackwell Science Ltd.

\section{Author Profile}

Eva Marie Codamon-Dugyon obtained her B.S. in Journalism at the Lyceum of the Philippines University, Intramuros, Manila in 1998. She finished her M.A. in Language at St. Mary's University, Bayombong, Nueva Vizcaya in 2009 under a scholarship grant of the Commission on Higher Education (CHED). On the summer of 2015, she graduated her degree in PhD by research work at Nueva Vizcaya State University (NVSU) as a special grantee of the Ifugao State University (IFSU) Faculty and Staff Development Program. The author is currently the Director of Extension and Training Department of IFSU where she is a faculty member of the College of Advanced Education with a rank of Associate Professor 1. 